\title{
Confirming the Existence of the Kingdom: The Efforts of Territorial Consolidation and Formation of Cultural Identity During the Reign of Hamengku Buwana I, 1755 - 1792
}

\author{
Sutarwinarmo, ${ }^{1 *}$ Agustinus Supriyono, ${ }^{2}$ Dhanang Respati Puguh ${ }^{2}$ \\ ${ }^{1}$ Arsip Nasional Republik Indonesia \\ ${ }^{2}$ Master Program of History, Faculty of Humanities, Diponegoro University \\ "Corresponding Author: sutarwinarmo@gmail.com
}

Received:

30 November 2017

Accepted:

18 December 2017

\section{Abstract}

This article discusses the efforts of territorial Consolidation and formation of cultural identity during the reign of Hamengku Buwana I. This article is written using historical method and utilizing primary sources in the form of VOC archives stored in the National Archives of the Republic of Indonesia and Java manuscripts stored in Yogyakarta Sultanate, as well as secondary sources in the form of articles and books. After Giyanti Agreement in 1755, Sultan Hamengku Buwana I attempted to consolidate his territory through negotiation, dispute settlement and law enforcement in order to preserve the sovereignity and territorial integrity of his kingdom. He also developed Ringgit Swargen, Yogyakarta style leather puppets that have different shape from Surakarta style leather puppets developed by Surakarta Sunanate as one of the cultural identity of Yogyakarta Sultanate. Leather puppet show was used to control the areas that were in the territory of the Sultanate of Yogyakarta, as the leather puppet show performed outside the palace must obtain permission from the palace puppet master. The efforts of Sultan Hamengku Buwana I failed, due to the conflict that caused the war destroyed the boundaries and the peace agreement that had been made.

Keywords: Giyanti Agreement; Territorial Consolidation; Cultural Identity; Hamengku Buwana I; Yogyakarta Sultanate; Surakarta Sunanate.

\section{Introduction}

In the concept of the agrarian kingdom of Java, land becomes the foundation of livelihood and the symbol of wealth. As a source of income, the control of land and the population becomes crucial, so the boundary is maintained until the last drop of blood. In the 18th century after Java lost the sea trade, the exploitation of the land became the sole source of income of Mataram kingdom.

With regard to the importance of land exploitation as the sole source of livelihood, the control of the land and its population became the seizure of the 
Javanese kings in the 18th century. The seizure of Java regions continued, until the Java War of Succession III. The power struggle between Sunan Pakubuwana III against Prince Mangkubumi ended after the signing of Giyanti Agreement on 13 February 1755 consisting of nine articles and dividing the territory of Mataram into two (Arsip Keresidenan Surakarta No. 48, ANRI). VOC acknowledged that Mangkubumi ruled half of Mataram and was inaugurated as the first king of Yogyakarta with the title of Sultan Hamengku Buwana I, who was also entitled to some parts of Mataram, while the remaining half was controlled by Sunan Paku Buwana III, the king of Surakarta.

Before splitting into two kingdoms, according to Rouffaer, at least until the time of Sunan Paku Buwana II, the region of Mataram was grouped into three parts. First, State as the central of the capital, a residence of kings and nobles and court officials. Second, Great State, a territory where there was appanage land or lungguh for kings, nobles, and court officials. Third, Manca Negara was the outer region, ruled by the regents whose land yield was paid once a year to the king of Mataram (Rouffaer 1988: 5-6). After Mataram was divided into two, the territory of the Great State and the region of the Manca Negara forced to share equally (sigar semangka). The division in Manca Negara was divided into each region while in the Great State, the two kings got the same amount of area, and therefore the division was done by village (Tijdschrift voor Nederlandsche Indie 1844).

According to Hageman, in 1755 the area of Surakarta was estimated to include 85,450 cacah or 512,700 lives (Hageman, 1860: 311), while the Sultan's regions in 1755 included 87,050 cacah or about 522,300 lives (Hageman 1860: 316). The details were: in Great State Sunan received 53,100 cacah plus 32,350 Manca Negara, while the Sultan obtained the Great State of 53.100 cacah plus the 33,950 cacah of Manca Negara. This part of the Sultan in the Manca Negara had an excess of 1,600 cacah as a compensation, since the Sultan only got East Manca Negara and did not have the Western Part of Manca Negara, namely Banyumas, the area of Patih and his brother-in-law, Danureja I, since Banyumas entirely fell into Sunan (Rouffaer 1988: 7-8).

In practice, there were some difficulties about the technical division of the two royal territories, since it could not be immediately divided, the limit could not be determined precisely. In fact, the problems in security affairs arose and resulted in riots that began a war between the two kingdoms. Therefore, the existence of the Kingdom of Yogyakarta as a newly established country always had integrity threat. In connection with the complexity of the division of the region, this paper examines two issues. First, what factors hinder the division of the kingdom and cause the difficulties of territorial consolidation? Second, because the integrity of the kingdom was threatened, what efforts that Sultan Hamengku Buwana I did in maintaining the existence of his kingdom? To examine the problem, historical method is used and it consists of four stages, namely testing and analyzing records and past relics through heuristics, criticism (internally and externally), interpretation and historiography or historical writing (Gottschalk 1983: 32). 


\section{Territorial Consolidation of the Kingdom}

After Giyanti Agreement in 1755, the division of the royal territory was not immediately applicable, because from the beginning there had been an error in the setting of the boundary. This occurred because the territories of the two kingdoms were not divided in the form of a unified territorial unit. In the fertile lands in which the official lands of Mataram officials were located, including Pajang, Mataram, Bagelen and Kedu, the two kings obtained the same rights. Concerning this matter, Peter Carey argues that the complexity of solving the problem of territorial division in Giyanti Agreement 1755 is caused by the village lands in the Great State that should be divided between Surakarta Sunanate and Yogyakarta Sultanate, so the territory of the two kingdoms became incomplete. According to the Dutch report, Sultan Hamengku Buwana I insisted on a complicated division of land in the Great State territory. This was necessary to ensure that the most fertile lands were evenly split; and closed the possibility for the Sunan to plan an attack to Yogyakarta Sultanate of territory without the knowledge of the Sultan, because the location of the villages of both of them were directly adjacent (Carey 2012). Hageman considers the division of territory as quite difficult, technically because each high and low noble, in every region, local, and village after declaring loyalty to the king, was considered under the scope of the kingdom (Hageman 1860: 316).

The division of the villages of the Great State resulted in the Sunan and Sultan's lands being irregular, since the boundaries of the villages were not known properly. The situation often leads to protracted territorial disputes. Prapto Yuwono illustrates that theoretically on Giyanti Agreement 1755, it was meant to solve the problem of power struggle, but the actual situation and condition of the realization of the division of the region actually added more problems because the areas were dispersed irregularly. As a result, there was an overlap in terms of ownership and people's obligation. The life of the people of Central Java during the division of the region, especially the administrative and bureaucratic problems experienced chaos (Yuwono 2003: 17). For example in the case of police supervision, many criminals who committed crime in the sultan's territory, fled to the sunan area, and vice versa, making it difficult for both parties to be proceeded legally (Tijdschrift voor Nederlansch Indie 1844: 134). Apparently in addition to the political tensions of the high-level elite at the center, people in the border area also faced their own problems, such as the loss of land as a source of livelihood for being deprived by new rulers, or because they were forced to give up the land for the agreement (Tijdschrift voor Nederlansch Indie 1844: 18).

Another problem that adds difficulties is the size of the area using the cacah unit. Some historians differ in interpreting the word cacah. Ricklefs explains that the word cacah has some additional meanings depending on the context. Originally cacah was a count unit; in the Javanese government this word means one household or the amount of land needed to support one household. One of its main functions as an administrative unit is in the military. The number of cacah controlled by kings, princes, or local officials is an indication of the size of the army that can be deployed 
immediately. Therefore, cacah shows the military strength and political power of a figure. There is strong allegation that the cacah number in the appanage shows the number of armed soldiers who can be deployed immediately with the assumption that the appanage owners gain loyalty from all their subordinates (Ricklefs 2002: 672673). Denys Lombard gives a conclusion that the meaning of word cacah is the main family as a taxpayer unit (Lombard, 2005: 35-46). Meanwhile, Soemarsaid Moertono defines the word cacah as a term used to designate the size of the area of control in terms of taxable land area (Moertono 1985: 144).

In the opinion of Djuliati Suroyo, the king of Java was the owner of the land who controlled the population and all the lands in his territory. Therefore, the king of Java focused on controlling human and taxes imposed on humans in cacah, not in the land. Therefore, the king of Mataram basically did not control the land if he did not control the population. In this case, it should be emphasized that the power of the king is not separated between the control of human or land, because both are one unity. At a time when the population was still scarce and the land was still large, the tax was determined from the number of cacah (farmers who worked the fields or produced). When all the land had become agricultural land, the tax was determined by the area of land (jung). The mandatory work was only as an in-kind tax that was frequently paid in the form of money (Suroyo 2000: 63-64). The above opinion expressly distinguishes the notion of cacah and jung; cacah refers to people, whereas jung refers to land. Therefore, it is an error to equate cacah to jung (in the 18th century) that have different uses.

Raffles who had served as Lieutenant Governor General of the Dutch East Indies in 1811-1816, distinguishes the notion of cacah and jung. Cacah is defined by the family, while bahu and jung are the main standard of size unit for land in Java, in addition to the other two land size units, i.e., bawat and cengkal (Raffles 2008: 901). With reference to the word cacah which means family, then the division of the area is always associated with the division of the population. Sometimes the population in several villages located side by side was subject to two different kingdoms, even the same villages were sometimes partially subjected to Surakarta Sunanate and some are subject to Yogyakarta Sultanate. In some places, the villages belonging to the Sultan were surrounded by Susuhunan land, while the villages of Susuhunan surrounded by the land of the Sultan (Veth 1912: 183).

It was so difficult to divide the land associated with the number population, let alone the irregular land location and its population that always contradictory. These situations and conditions make it difficult to achieve peace between the two kingdoms, let alone Raden Mas Said and his troops who were still continue the rebellion and disrupted the border area. On Thursday, February 24, 1757, Raden Mas Said of his own willingness surrendered to Susuhunan. Then by the governor Nicolas Hartingh, on 17 March 1757, a negotiation was held in Salatiga. He was appointed as Pangeran Miji (the chosen one) given the title of Mangkunegara I, and the appanage land of 4000 cacah taken from the Susuhunan region (Nurhajarini \& Gunawan 1999: 95). 
After the situation was secure, Yogyakarta Sultanate urged the Surakarta Sunanate to realize the division of the Great State territory. On September 26, 1757, in the village of Klepu (located between Klaten and Delanggu, on the edge of Surakarta-Yogyakarta road) both parties made a deal and declared a list of villages belonging to Sunan and Sultan, known as Kitab Klepu (Nurhajarini \& Gunawan 1999: 139; Rouffaer 1988: 6).

Six years later the boundaries of the Yogyakarta Sultanate became unclear as a result of the war. Every time personal conflict happened, the kings and rulers always used war as settlement. This fact became one of the factors of unstable security situation and resulted in increasingly unclear border area. The subject matter was the crisis of 1763, regarding the divorce of Bendara Queen, the daughter of Sultan Hamengku Buwana I with her husband (Mangkunegara I) who went back to his father in Yogyakarta. The reason was that the Bendara Queen could not stand the behavior of Mangkunegara I, even if Bendara Queen was forced to return to her husband, she would be desperately committing suicide. As he concerned about his daughter, Sultan sent a letter in July, 26 ${ }^{\text {th }} 1763$ to Willem Hendrik van Ossenbergh (East Coast Governor in Semarang), to seek approval of his daughter's divorce with Mangkunegara I (Arsip Keresidenan Yogyakarta No.10, ANRI)

Mangkunegara I demanded the return of his wife. But his wish was not fulfilled by the Sultan, causing the anger of Mangkunegara I, who immediately prepared his troops to seize his wife and attacked Yogyakarta Sultanate. Both Mangkunegara I and Sultan Hamengku Buwana I did not want to compromise, as a result, a war in the border area occurred (Ricklefs 2002: 178).

On October 1763, Governor van Ossenbergh departed from Semarang to Surakarta and Yogyakarta, to mediate the dispute. Sunan Paku Buwana III suppressed Mangkunegara I to be soft and accepted the proposed divorce with Bendara Queen. If Mangkunegara I refused, then he would face three enemies, namely Yogyakarta Sultanate, Colonialist, and God. Finally Mangkunegara was willing to make peace and divorced his wife and discouraged his intention to ask for the return of Bendara Queen. The battle ceased in December 1763 and the seized villages began to be returned to the rightful rulers during the first month of 1764 (Ricklefs 2002: 178-181).

Although the war for three months had stopped but the boundaries of the two kingdoms was unclear, due to the village seizure during the war. The problem solving of the territorial dispute was not completed until the East Java Sea Governor van Osenbergh was replaced by Johannes Vos in 1765. In November 1768, Johannes Vos invited the parties in dispute, Sunan Paku Buwana III (including Mangkunegara I) and Sultan Hamengku Buwana I. The Patih of Sunan and Sultan were accompanied by a group of priyayi gathered in Semarang, and made a new contract, regarding the distribution of disputed villages and subjects (Corpus Diplomaticum Neerlando Indicum zesde deel: 305).

Sunan Paku Buwana III and Sultan Hamengku Buwana I subsequently entered into a new contract agreement, represented and declared by their two patihs, Raden 
Adipati Mangkupraja I (patih Surakarta) and Adipati Danureja I (patih Yogyakarta), witnessed by the Governor of Java East Coast. The main reason for the renewal of this contract aimed to create a peace that was sincerely expected by both parties by improperly giving boundary to the places and villages they had from other parties illegally, sharing all that had been handed over in equal measure since the peace was valid. In addition, there were also records of uninhabited lands which were not mentioned in the previous agreement. Both parties must abide by the rules contained in the contract consisting of four articles. After the ratification of the contract made in Semarang on November 28, 1768, the agreement on September 26, 1757 was revoked and deemed invalid (Arsip Keresidenan Yogyakarta No. 256).

The dispute settlement efforts in some borders of Yogyakarta Sultanate did not show any real results, as in returning the seized villages to the right were always associated with the number of people living (negori and cacah), so the listing of the territory took a very long time. Sultan Hamengku Buwana I was not satisfied with the settlement of the dispute which in some places still left the problem. In May 1770, Sultan Hamengku Buwana I sent a letter to Governor Johannes Vos about a land dispute near Laroh, which mentioned that Sultan demanded the 50 cacah belonging to the Sultan to be returned to the Sultan of (Arsip Keresidenan Yogyakarta No. bendel 12, ANRI).

The central government ordered Governor Johannes Vos in Semarang to establish a Commission in charge of investigating unfinished territorial dispute. The Commission comprised of Lieutenant Court Hendrik Reygens, vandrig Adriaan van Rijk assisted by Onderkoopman and translator Carel Philip Boldze and Tumenggung Citradiwirya and Tumenggung Cengkalsewu, Ngabehi Cakradipa, to monitor the disputed territories and demanded for the return of the seized negori and cacah. The commission's report, made in Semarang on October 1, 1770, noted a variety of problems with a long list of negori and cacah, and concluded that there were many differences in the number of counts and inconsistencies of villages recorded in Klepu, both in Pajang, Laroh, South ("Ingekomene stukken wegens opgenomene vorstenlanden contracten tusschen bij de Rijksbestuurders wegens het landschap van November 1770").

However, the commission investigation was not immediately followed up. It was not until 1773 at the time of Governor Johannes Robbert van der Burgh (successor of Johannes Vos), through a great deal of effort to deal with every plot of land owned by the two kingdoms (Corpus Diplomaticum Neerlando Indicum, zesde deel, MXCV Vorstenlanden, 382). On November 2, 1773 in Semarang the second Deed was signed. The signing of the deed was attended by representatives of Susuhunan Paku Buwana III, Raden Adipati Sasradiningrat and representative of Sultan Hamengku Buwana I, Raden Adipati Danureja I (Nurhajarini \& Gunawan 1999: 139). The deed was made in two languages (Dutch-Java) in 1773 containing a list of negori and cacah in the territory of the Great State. Each negori and cacah in the Great State shall be returned and under the directive of a designated official. Each region was lead by the people of the level of wedana and subdivided by officials. The 
Sultanate of Yogyakarta, Kedu was under Wedana Natayuda, Mataram was under Suramenggala Prince, Bagelen was under Ngabehi Danayuda, Rema was under Wedana Kartanagaran, Sukowati was under Santayuda, Pajang was under Kertawijaya (ANRI, Arsip Keresidenan Yogyakarta No. 258).

A year later, the deed was ratified with a contract on April 26, 1774. The contract was made in the name of Susuhunan Paku Buwana III and Sultan Hamengku Buwana I, and witnessed by the Governor of East Coast of Java, consisting of five articles. The point was that the two kings fully approved the new list of lands, composed by the two patihs in Semarang, on November 2, 1773, revoked Klepu's Book (Het boek van Cleppoe), restored the ownership of seized lands to their rightful owners, prevented the robbery of land or livestock and other goods, and punish the perpetrators of land robbery. The function of the two kings contract in 1774 was as a reinforcement of deed that had been made first by the two patihs containing the land (negori) and cacah lists in 1773 in Javanese and Dutch languages (Arsip Keresidenan Yogyakarta No. 259, ANRI).

In addition to the renewal of deeds and contracts, another attempt to resolve disputes was the approval of new legislation, which officially governed the relationship between the two kingdoms. Ricklefs thought that the first Javanese law applied was Angger Ageng (Great Book of Law), which contained the general rule of the relationship between the two kingdoms, approved and declared by Patih Danureja I (Yogyakarta) and Patih Sasradiningrat I (Surakarta) on 6 Sura 1697 Java or 21 April 1771, and updated in 1782, 1786, 1789, and $1792 \mathrm{M}$. This law aimed to establish legal procedures to resolve the issue of crime and disputes that crossed the boundary between the regions of Surakarta-Yogyakarta. For example, the settlement of penalties for illegal land robber, destroyers of rice fields, waterways, or roads. The second Javanese law was Angger Arubiru (Book of Riot Law) which was approved and declared by the two patihs in 11 Sura 1699 Java or 4 April 1773, and was renewed in 1782 and 1786. This law aimed to end the dispute between Surakarta-Yogyakarta in terms of land ownership disputes, as well as on the prohibition of wearing certain clothing and acts for the offender (Ricklefs 2002: 256-257).

According to Prapto Yuwono, the enactment of Javanese Law together between the two kingdoms indicates the existence of mutual social control interests between Kasultanan and Kasunanan (including Mangkunegaran), in anticipation of various upheavals arising after the split of Mataram in post-Giyanti Agreement 1755 (Yuwono 2003: 3). Furthermore, Prapto Yuwono also explains that in the structure of Javanese Law of the 18th century, both Sunan and Sultan were the highest authority or the highest source of Javanese law. As for those were subjected to the Javanese law were those who were legally registered as the citizens of the two kingdoms, such as ordinary people, the king's officials, high officials, nobles even the Chinese and European people. In short, anyone living in the kingdom of Surakarta - Yogyakarta, might be subject to Javanese law at that time (Yuwono 2003: 74-75).

\section{Establishment of Cultural Identity}


Although a new deal was established in 1773-1774 and the enactment of Javanese law altogether, it did not mean that hostility had ceased. Anthony Day declared that after the Giyanti Agreement in 1755 to the end of the 18th century, there was no longer a large Baratayuda-style civil war. Surakarta Sunanate and Yogyakarta Sultanate continued to compete for hegemony in Central Java. Both were in covert resistance, expressed through the rivalry of cultural splendor, such as dance, shadow puppet performances, rather than in open war (Day 1975: 26).

Moedjanto explains that throughout the history of the Mataram dynasty, as a whole the new king on the throne always felt his position was threatened (Moedjanto 1987: 29). Likewise with Sultan Hamengku Buwana I as the new king, he must consolidate his new position as the holder of supremacy in his kingdom. There was a political and military pattern, religious magical pattern, and cultural pattern of consolidation efforts (Moedjanto 1987: 41).

One of the cultural consolidation efforts was the formation of Yogyakarta Sultanate cultural identity. This was carried by Hamengku Buwana I with the development of Yogyakarta style leather puppet, known as Ringgit Swargen which had different characteristics from Surakarta style. The recording done by the courtiers of Yogyakarta Palace showed that Ringgit Swargen was amounted to 430 pieces, but then got additional leather puppets from some of the next sultans of Yogyakarta by 29 pieces so the total was 459 pieces (Archive Kagungan Dalem Ringgit Swargen Keraton Yogyakarta, 12 April 1994). Leather puppets created during the Sultan Hamengku Buwana I became one of the collections of Yogyakarta Sultanate puppet, and became the parent for leather puppet body in the future.

Sultan Hamengku Buwana I ordered the making of this leather puppet because in the field of culture, Kasunanan Surakarta was more established. As was known, the shape of leather puppets in Surakarta during the Sunan Paku Buwana III experienced a rapid development, especially at the time of B. R. M. Gusti Subadya who was born in 1768 grown up and appointed as Crown Prince (later reigned as Sunan Paku Buwana IV). According to Serat Sri Radya Laksana as quoted by Sayid, the Crown Prince of Surakarta was the one who made a change of leather puppet of which pattern was modeled according to the leather puppet of Sunan Paku Buwana II, the leather puppet of Kyai Pramukaya. The shape of leather puppets was totally transformed, among others are the body of giant puppets and two-eyed monkeys that was turned into one-eye, so their faces appeared to be aslant not sideway, and this became a special feature of Surakarta leather puppet (Sayid 1981: 23).

Crown Prince of Surakarta was a great unmatched artist in Surakarta. In the short time from 1782 until 1786, three boxes of leather puppet were created, namely Kyai Mangu, Kyai Kanyut, and Kyai Pramukanya Kadipaten that were used for puppet show in Surakarta Kingdom until Crown Prince of Surakarta ascended the throne in 1788. After occupying the Sunan Kasunanan throne with Sunan Paku Buwana IV, he still ordered to make leather puppet with extended size (dijujud) as much as two boxes, so Surakarta style leather puppet was bigger than Yogyakarta style leather puppet. The two shadow puppets were named after the Kyai Jimat leather puppet 
finished in 1791 and Kyai Kadung was completed in the year of Alip 1721 or 1795 AD (Sayid 1981: 26).

Meanwhile, in Ringgit Swargen as a Yogyakarta style leather puppet, the characteristic that was retaining such a Mataram time leather puppet was found; such as giant faces and two-eyed monkeys, Bima leather puppet did not wear pants (kampuh) but only wear loincloths. This was reminiscent of the Bima statues during the Majapahit period spread in several places in Central and East Java, such as Sukuh Temple, Mount Wilis, Kediri, and so on. The creation of Bima leather puppet by Sultan Hamengku Buwana I as mentioned might be a deliberate attempt to connect the existence of Mataram (Yogyakarta Sultanate) as the successor of the Majapahit tradition. According to Vlekke, Sultan Hamengku Buwana I was one of the king who was very fond of listening to the palace poets of Yogyakarta read babad like Pararaton and Majapahit glory story. From the story of the chronicle, he took the advice and guidance of Majapahit's glory in the past (Vlekke 1967: 224).

In addition, another shape that distinguished Ringgit Swargen created by Hamengku Buwana I with Paku Buwana IV style shadow puppet was the figure of gods. All the shape Ringgit Swargen god figures were returned as in the time of Mataram, which neither wearing clothes nor shoes, like the figure of Batara Guru. According to Sayid, the progress of leather puppet was affected by Dutch presence in Java. For example, at the end of Kartasura, many puppets of different colors, puppets wearing clothes and shoes were created (Sayid 1981: 54). Therefore, the creation of the figures of Ringgit Swargen god that deprived the European elements, not wearing clothes and shoes, can be assumed as a symbol of the attitude of Sultan Hamengku Buwana I government as king of Yogyakarta who was less willing to accept European domination (Ricklefs 2002: 671).

Another example of difference is found in the Yogyakarta-style Rampogan leather puppets found on Ringgit Swargen. If we look closer, Yogyakarta style Rampogan leather puppet is the personification of the forces of Yogyakarta Sultanate during the Sultan Hamengku Buwana I. Rampogan is leather puppet that describes the attacking troops. However, the shape of Yogyakarta style Rampogan leather puppet is different from Surakarta style rampogan leather puppet. If Surakarta style rampogan leather puppets has a shape of row with stiliran puppet face arranged in storied, then Yogyakarta style Rampogan leather puppet is royal forces with ordinary human face lined up and dressed like Yogyakarta Sultanate troops, among others: Bugis soldiers are dressed and wear black hat, Surakarta soldiers are in white shirt and wear udheng mondholan nyekok, and so on. The position of Yogyakarta style Rampogan leather puppet reflects the attitude of Sultan Hamengku Buwana I who always strengthens his army and always stands ready to face the threat of enemies from outside. This is reflected in the shape of Yogyakarta style Rampogan leather puppet in front of the readiness of troops with canons and guns (Moerdowo 1982: 29).

Broadly speaking, the shape of Yogyakarta style leather puppets can be described as follows. The shape of knight shadow puppet characters (especially the 
figures of jangkahan leather puppet) the position of its legs are stepped wide, the back of the foot slightly sloping which shows puppet moving. This shape describes the king and nobles of Yogyakarta Sultanate who have a courageous, expressive, and dynamic attitude. Meanwhile, the female leather puppets describe the puppet that stops moving marked with folds of hem fabric in the front position. This shape describes the style of dance position of Yogyakarta Keraton princess called as nggrodha (Moerdowo 1982: 36). This is the difference between the shapes of Yogyakarta style leather puppets and Surakarta style leather puppets. The legs position of Surakarta style puppet was like a person standing upright and not moving (ringgit tancep).

The differences between the two styles may have been compiled at least at the end of the reign of Sultan Hamengku Buwana I. However, due to the seizure of archives by the European army, the source of information was loss. Manuscripts of the different tatah sungging leather puppet of Yogyakarta and Surakarta styles were copied and rewritten by typing, from R.M. Jayadipura and accepted by G.P.H.Tejakusuma. The manuscript contains a picture of the puppet sketch which explains the differences between the two styles, it also explains that the difference of the shape was based on the lesson explained by Kertiwanda, Jayaprana's student, the courtier of Sultan of Hamengku Buwana I (mekaten wau miturut piwulangipun penatah sepuh nama Kertiwanda, muridipun Ki Jayaprana, abdidalem ingkang Sinuwun Suwarga, jumeneng dalem ing Ngayogya sapisan - it is according to the teachings of the elders of the name of Kertiwanda, the disciple of Ki Jayaprana, courtier of Sinuwun Suwarga, in Ngayogya) (Fakultas Ilmu Pengetahuan Budaya UI, G-187).

In this case, leather puppet is possible to be used as a means of spreading the symbol of the palace identity, compared to living puppet, because until the end of the 19th century, living puppet is still an art monopolized by the palace, only since 1918 living puppet began to spread outside the palace fort (Soedarsono and Narawati, 2011: 104). According to Soedarsono, the art of leather puppet has grown rapidly as a palace art and also as folk art since the 18th century. In addition as an aesthetic show, leather puppet also preserves its ritual function in the villages, while in the palace leather puppet is performed for the anniversary of Sultan's birth at Yogyakarta palace (Soedarsono 1997: 363). As a means of ritual, the event of village cleaning and ruwatan in the countryside is the manifestation of it. According to Victoria M. Clara van Groenendael, the function of leather puppet as ruwatan ritual has begun since Mataram was governed by Susuhunan Anyakrawati. He also issued a ban on wayang beber performances as a village cleaning ceremony. Instead, the Mataram people held a village cleaning show with leather puppet (Groenendael 1985: 58). While since Mataram Amangkurat I ruled, there was a palace puppeteer as Mataram court official who specifically held ruwatan by performing leather puppets in the villages. If a village was planning to clean the village and ruwatan ceremonies, it was required to seek approval from the palace puppeteer. The request for permission was related to the ruwatan ritual that was considered to be heavy because it could bring harm to the villagers (Groenendael 1985: 59). This last function 
can be seen as a tool of the palace to control the villages in the Sultan region, because ruwatan performance in rural areas must get permission of palace puppet master.

However the sultan's efforts failed. The personal conflicts of the kings caused a crisis in Surakarta in 1790 involving Yogyakarta Sultanate. The conflicts over territorial disputes in 1790 still left the issue until the reign of Sultan Hamengku Buwana II, including the size of the land, the seizure of rice fields, livestock, and inter-village irrigation channel disputes (Carey 1980: 138-141). The limits and size of the land remained unclear, no serious effort to solve the problem in a better direction, because Sultan Hamengku Buwana I was old, in poor health, and alienated himself to Krapyak until his death on 24 March 1792 (Ricklefs 2002: 561-562). While the VOC government's proposal on measuring and calculating the land that had been conceived by the Governor of Siberg in 1787 was delayed by Jan Greeve (Hageman 1860: 317).

That fact is easy to understand as VOC financial condition degenerated toward the end of the $18^{\text {th }}$ century, making it impossible to take measurements that cost money and effort. As it was known, over the years, VOC's earnings were declining, while corruption was affecting almost all VOC employees, even this loss of corruption was 50 percent (Niel 2005: 45-46). In 1791, towards the end of the reign of Sultan Hamengku Buwana I, VOC's debt had reached 100 million guilders. The huge debt occurred because the income received on the VOC cash was very small, but the budget spent grew larger and far exceeded the cash income. The amount of such debt was for the maintenance of hundreds of ships, soldier (Europeans) salary about 20,000 people, administrative staff, sailors, warehouse maintenance, workplaces, offices, hospitals, and church (Kresna 2011: 186).

\section{Conclusion}

After Giyanti Agreement in 1755 there were some difficulties regarding the technical division of the kingdom caused by two inhibiting factors. The first factor is from the beginning in the division of kingdom there had been a mistake on the determination of territorial boundaries, because the territory of the two kingdoms was not divided in the form of a unified territorial unit. In the fertile areas where the appanage lands of official located, the two kings obtained equal rights, divided by village, so the land of the two kings became unclear. In addition, there is also a problem on size of the area using the cacah unit that in the 18th century that refers to the size of the family. As a result, the population was divided into two, so several adjacent villages were sometimes subject to two different kingdoms, even the same villages were sometimes partially subjected to Surakarta Sunanate and some were subject to Yogyakarta Sultanate. The situation often triggered hostilities between villagers. The second factor is the conflict of personal interests of the rulers that encouraged war and territorial violations, such as the conflict of 1763, about the divorce of Mangkunegara I with Bendara Queen (daughter of Hamengku Buwana I). The three-month war destroyed the boundaries of the region and the seizure of the Sultan's villages took place, so rearrangement of royal boundary was required. 
After the war and the prolonged dispute, to maintain the sovereignty of the territory and integrity of his kingdom, the Sultan made various efforts. These efforts were carried out by negotiation and dispute settlement, as well as law enforcement to prevent various crimes in the border area by imposing joint Javanese law in the two kingdoms. In addition, other effort was made through the cultural way with the formation of cultural identity of Yogyakarta Sultanate. Establishment of cultural identity was done with the development of Yogyakarta style leather puppet that has different characteristics with Surakarta style. As an art that developed in the 18th century, shadow puppets have double functions. In addition as an aesthetic entertainment and tool for encouraging heroism, it also serves as a means of ritual in the event of clean village and ruwatan in the countryside. The last function also works as a tool to control over the villages in the Sultan region, because ruwatan performances in rural areas must get permission from the palace puppeteer. However, the sultan's efforts failed, the crisis in Surakarta in 1790 involving the Yogyakarta Sultanate in the war conflict destroyed the boundaries and the peace agreement that had been made. VOC was unable to resolve the consequences of the conflict, due to financial decline. Until the departure of Sultan Hamengku Buwana I in 1792, various border issues did not come to an end and it was a reflection of the failure of territorial Consolidation efforts and the standardization of a country.

\section{References}

"Arsip Kagungan Dalem Ringgit Swargen Keraton Yogyakarta", 12 April 1994. Kawedanan Ageng Punakawan Kridha Mardawa Yogyakarta.

Arsip Keresidenan Surakarta No. 48. "Copie korte contracten tussen de Oost Indisce Compagnie en het Hof van Mataram 16-04-1755". ANRI.

Arsip Keresidenan Yogyakarta No. 256. "Kopij boek van contracten Djogjacarta”. ANRI.

Arsip Keresidenan Yogyakarta No. 257. “Ingekomene stukken wegens opgenomene vorstenlanden contracten tusschen bij de Rijksbestuurders wegens het landschap van November 1770". ANRI.

Arsip Keresidenan Yogyakarta No. 258, “Net Javaas Contract, Register der landen van den Sultan Djogja, 1773-Punika Serat Pemut Menggah Bumi Pasiten Kanjeng Sultan Kadamel ing Semawis 1773". ANRI.

Arsip Keresidenan Yogyakarta No. 259. “Acte van contract tussen den Kaizer en Sultan van Java wegens de landen die zij prossedeeren vermeld bij Samarangsch secreeten brief den 5 Juni 1774". ANRI.

Arsip Keresidenan Yogyakarta No. bendel 12. "Surat Sultan Hamengku Buwana I kepada Johannes Vos tanggal 25 Mei 1770 atau bulan Suro tahun Ebe 1696". ANRI.

Arsip Keresidenan Yogyakarta No.10. “Surat Sultan Hamengku Buwana I kepada Willem Henderik van Ossenbergh tanggal 26 Juli 1763 atau 9 Muharam tahun Wawu 1689". ANRI. 
Carey, P. B. R. (1980). The Archive of Yogyakarta Volume I Documents Relating to Politics and Internal Court Affairs. London: Published for The British Academy by Oxford University Press.

Carey, Peter (2012). Kuasa Ramalan Pangeran Diponegoro dan Akhir Tatanan Lama di Jawa, 1785-1855. Jakarta: Kepustakaan Populer Gramedia dan KITLV.

Corpus Diplomaticum Neerlando Indicum, zesde deel, MLX Surakarta-Yogyakarta.

Corpus Diplomaticum Neerlando Indicum, zesde deel, MXCV Vorstenlanden.

Day, Anthony (1975). "Kraton Ambon: Myth and History in the Late Nineteenth Century", Conference on Modern Indonesian History. 18-19 July 1975. Madison: Center for Southeast Asian Studies, University of Wisconsin.

Fakultas Ilmu Pengetahuan Budaya Universitas Indonesia G-187. "Naskah Katrangan Namaning Tatahan Ringgit Watjoetjal Sarta Soenggingan Sakrampoengipoen, Ingkang Beda ing Nagari Soerakarta, akalijan Nagari ing Ngajoegjakarta", 15 Agustus 1942.

Gottschalk, Louis (1983). Mengerti Sejarah. Terjemahan Nugroho Notosusanto. Jakarta: UI Press.

Groenendael, Victoria M. Clara van (1985). The Dalang Behind The Wayang Dordrecht: Foris Publications.

Hageman, J. Cz., J. (1860). “Geschied-En Aardrijkskundig Overzigt van Java op het Einde der Achttiende Eeuw." Tijdschrift Bataviaasch Genootschap (TBG), Jilid IX.

Kresna, Ardian (2011). Sejarah Panjang Mataram, Menengok Berdirinya Kerajaan Yogyakarta. Yogyakarta: Diva Press.

Lombard, Denys (2005). Nusa Jawa 3: Silang Budaya Warisan Kerajaan-Kerajaan Konsentris. Jakarta: P.T.Gramedia Pustaka Utama \& EFEO.

Moedjanto, G. (1987). Konsep Kekuasaan Jawa Penerapannya oleh Raja-raja Mataram. Yogyakarta: Penerbit Kanisius.

Moerdowo, R. M. (1982). Wayang its Significance in Indonesian Society. Jakarta: P.N. Balai Pustaka.

Moertono, Soemarsaid (1985). Negara dan Usaha Bina Negara di Jawa Masa Lampau: Studi tentang Masa Mataram II, Abad XVI sampai XIX. Jakarta: Yayasan Obor Indonesia.

Niel, Robert Van (2005). Java Northeast Coast 1740 - 1840, A Study in Colonial Encroachment and Dominance. Leiden: CNSW Publications.

Nurhajarini, Dwi R., and Gunawan, R. (1999). Sejarah Kerajaan Tradisional Surakarta. Jakarta: Departemen Pendidikan dan Kebudayaan.

Raffles, Thomas Stamford (2008). The History of Java, terjemahan Eko Prasetyaningrum, Nuryati Agustin, Idda Qoryati Mahbubah. Yogyakarta: Penerbit Narasi.

Ricklefs, M. C. (2002). Yogyakarta di Bawah Sultan Mangkubumi 1749-1792: Sejarah Pembagian Jawa, terjemahan Hartono Hadikusumo dan E. Setiyawati Alkhatab. Yogyakarta: Mata Bangsa.

Roorda, T. (2002). Javaansche Wetten, terjemahan Jumeiri Siti Rumidjah. Yogyakarta: Penerbit Kepel. 
Rouffaer, G. P. (1988). "Praja Kejawen" (Vorstenlanden), terjemahan Suhardjo Hatmosuprobo Yogyakarta.

Sayid, R. M. (1981). Ringkasan Sejarah Wayang. Jakarta: Pradnya Paramita.

Soedarsono, R. M. (1997). Wayang Wong: Drama Tari Ritual Kenegaraan di Keraton Yogyakarta. Yogyakarta: Gadjah Mada University Press.

Soedarsono, R. M. dan Tati Narawati (2011). Dramatari di Indonesia, Kontinuitas dan Perubahan. Yogyakarta: Gadjah Mada University Press.

Suroyo, A. M. Djuliati, 2000. Eksploitasi Kolonial Abad XIX. Kerja Wajib di Keresidenan Kedu 1800 - 1890. Yogyakarta: Penerbit Yayasan Untuk Indonesia.

Tijdschrift voor Nederlandsch Indie (TNI), Jilid III. 1844. Perpustakaan Nasional Republik Indonesia. Nomor A 191.

Veth. P. J. (1912). Java: Geographisch, Ethnologisch, Historisch, tweede deel. Haarlem: De Erven F. Boh.

Vlekke, Bernard H. M. (1967). Nusantara: Sejarah Indonesia. Kuala Lumpur: Dewan Bahasa dan Pustaka Kementerian Pelajaran Malaysia.

Yuwono, Prapto (2003). Sistem Hukum Jawa Abad ke- 18. Jakarta: Penerbit Wedatama Widya Sastra. 